\title{
DO THIRD MOLARS PLAY A ROLE IN SECOND MOLARS UNDERGOING ENDODONTIC TREATMENT?
}

\section{ABSTRACT}

Background and aim: This study evaluated the rates of second molars undergoing endodontic treatment due to partially or fully erupted lower and upper third molars.

Materials and Methods: Radiographic data from 579 patients were analyzed to calculate the rates of second molars undergoing endodontic treatment due to third molars and other reasons. Descriptive statistics were expressed as numbers and percentages for categorical variables. The chi-square test was used to determine the relationships between categorical variables $(p<0.05)$.

Results: The rate of second molars undergoing root canal treatment for reasons unrelated to third molars was statistically higher than that of second molars undergoing treatment because of third molars $(p<0.001)$. The rate of lower second molars with endodontic treatment was significantly higher than that of upper second molars $(p<0.001)$. There was no statistically significant difference between partially and fully erupted third molars causing root canal treatment of second molars $(p=$ $0.344)$.

Conclusions: Root canal treatment of second molars can be related to fully or partially erupted third molars. All preventive measures should be taken to avoid the need for root canal treatment.

Key Words: Dental caries, endodontics, root canal therapy, third molar.
*Betul Aycan Alim Uysal ${ }^{1}$

Bilal Latif Kaya²

Mehmet Burak Guneser ${ }^{1}$

ORCID IDs of the authors:

B.A.A.U. 0000-0002-6113-6927

B.L.K. $\quad$ 0000-0003-3592-8928

M.B.G. 0000-0003-0896-777X

${ }^{1}$ Bezmialem Vakif University, Faculty of Dentistry, Department of Endodontics, Istanbul, Turkey.

${ }^{2}$ Undergraduate Student, Bezmialem Vakif University, Faculty of Dentistry, Istanbul, Turkey.

Received : 05.02 .2021

Accepted $\quad: 02.05 .2021$ 


\section{INTRODUCTION}

The third molars are the last teeth to erupt and are the most posterior in the oral cavity. Consequently, the probability of lack of space for their eruption is high. ${ }^{1}$ If they are not impacted, they usually start to erupt between 17 and 21 years old. ${ }^{2}$ Third molar eruption and subsequent continuous positional changes can be related to diet, race, genetic history, and the use of the mastication apparatus. ${ }^{3}$

Third molars may cause pericoronitis, periodontal diseases, caries, cyst or tumor formations, and systemic infections. ${ }^{4}$ Partially erupted third molars show a higher incidence of symptoms than unerupted or fully erupted molars. ${ }^{5}$ A partially erupted tooth does not participate in mastication and offers more favorable conditions for the accumulation of bacteria than a fully erupted tooth. ${ }^{6}$ Moreover, pericoronitis associated with poor oral hygiene leads to food accumulation that cannot be cleaned by normal brushing and flossing, causing caries development. ${ }^{7}$

Winter classified mandibular third molar impaction according to the inclination of the long axis of the impacted third molar with respect to the long axis of an adjacent second molar. ${ }^{8}$ The various types of impaction in maxillary third molars are similar to those of mandibular third molars with respect to their orientation to second molars. Hence, Winter's classification has been adapted to maxillary third molars. ${ }^{9,10}$

External root resorption or deep caries can be seen on the distal surface of a second molar ${ }^{11}$ and are generally associated with the angulation of an adjacent third molar. ${ }^{12}$ Partially or fully erupted mesioangular third molars are associated with the development of caries in the distal aspect of the corresponding second molar because of difficulties in cleaning. ${ }^{13}$

Distal caries in a second molar is more difficult to detect clinically in the presence of a third molar. Deep caries triggers a severe inflammatory reaction in the pulp and may cause pulp necrosis. ${ }^{14}$ If these lesions remain undetected, they can progress and lead to the need for root canal treatment or extraction of the second molar. ${ }^{15}$ Distal surface caries on a mandibular second molar can lead to problems in restoration owing to the frequent occurrence of subgingival caries accompanied by severe destruction of alveolar bone. ${ }^{12}$ Second molars are generally considered more difficult to treat endodontically due to their anatomy and limited visibility and access. ${ }^{16}$ For patients in whom mandibular second molars are at high risk of developing carious lesions due to their proximity to mandibular third molars, preventive extraction of the latter may be recommended to improve the prognosis of the former. ${ }^{17}$

Although many studies have investigated lower third molars causing distal caries in second molars, ${ }^{11,12,15,18-20}$ no studies have examined second molars undergoing endodontic treatment because of both upper and lower third molars. The aim of this study was to evaluate second molars undergoing endodontic treatment associated with lower and upper third molars.

\section{MATERIALS AND METHODS}

The study protocol was approved by the Ethics Committee of Bezmialem Vakif University (decision no.545, date: 12.01.2020). Power analysis with $\mathrm{G}^{*}$ Power ver. 3.1.2 (University of Duesseldorf, Duesseldorf, Germany) was conducted to determine the sample size. An alpha level of 0.05 , a power of 0.80 and an effect size 0.01 for every variable were assumed when Independent t-Test was used to establish the significance of correlations. The estimated sample size was 383 patients. In this retrospective study, clinical and radiographic records of patients referring to the Faculty of Dentistry of Bezmialem Vakif University between January 2019 and February 2020 were collected. The study included 758 patients who were referred to the Department of Endodontics by the Department of Oral Radiology for second molar root canal treatment. The inclusion criteria were healthy patients without serious systemic diseases, and with the presence of a partially or fully erupted third molar and an adjacent second molar undergoing endodontic treatment. The exclusion criteria were as follows: second molars with vertical root fracture, traumatic injury and ankylosis; patients who were currently receiving orthodontic treatment; patients younger than 20 years and older than 51 years; patients 
without an adjacent third molar and an initial panoramic radiography. Of the patients, $179 \mathrm{did}$ not meet these criteria. The panoramic and periapical radiographs (Romexis Viewer, Planmeca, Helsinki, Finland) of 579 patients with endodontically treated upper or lower second molars were analyzed (Figure 1).

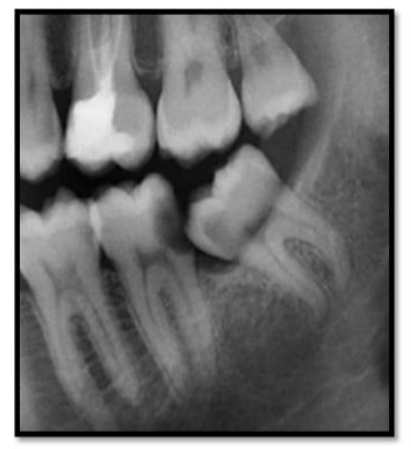

A

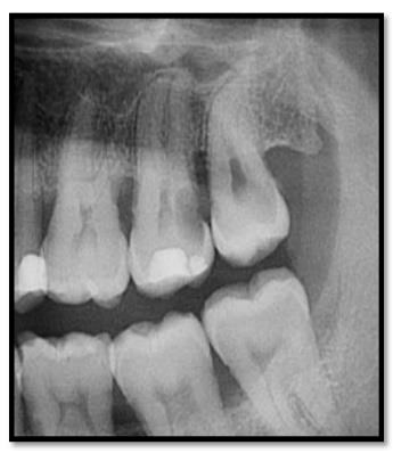

B
Figure 1. Examples of patients' panoramic radiographs. (A) A lower third molar with mesioangular angulation and $(B)$ an upper third molar with vertical angulation.

The power was recalculated to 0.95 using post-hoc analysis according to 579 second molar. It was observed that the sample size of the study was compatible with a power of 0.95 .

The eruption status of the third molars causing root canal treatment of second molars was determined on panoramic radiography. The rates of second molars undergoing root canal treatment because of third molars and for other reasons (such as prosthetic or iatrogenic causes, failed vital pulp treatments, and pulp and periapical pathologies) were calculated. The variables recorded were sex, age, location of the second molars undergoing endodontic treatment, and location, eruption status, and angulation of the third molars responsible for distal caries in the second molars.

Descriptive statistics were expressed as numbers and percentages for categorical variables. The chi-square test was used to determine the relationships between categorical variables. A zratio test was used to investigate the relationships between second and third molars. The level of statistical significance was set to $p<0.05$. IBM SPSS Statistics ver. 24 (IBM, Armonk, NY, USA) and Minitab ver. 17 (Minitab, State College, PA, USA) for Windows were used for the statistical analyses.

\section{RESULTS}

A total of 579 second molars of 279 (48.2\%) male and $300(51.8 \%)$ female patients were assessed in this study. Of the 579 patients, 258 (44.6\%) were aged $21-30,160(27.6 \%)$ were aged $31-40$, and $161(27.8 \%)$ were aged $41-50$. The number of second molars undergoing endodontic treatment because of third molars was higher in males, whereas the number of second molars undergoing treatment for other reasons was higher in females. However, the difference was not statistically significant $(p=0.284)$. No statistically significant differences were observed between second molars with endodontic treatment and the patients' ages ( $p$ $=0.869 ;$ Table 1 ).

Table 1. Reasons for Root Canal Treatment According to Patients' Demographic Data $(n=579)$

\begin{tabular}{|c|c|c|c|c|}
\hline \multirow{2}{*}{ Reason } & \multicolumn{3}{|c|}{ Sex } & \multirow[t]{2}{*}{$P$} \\
\hline & Male & & Female & \\
\hline Third molar & 71 & & 65 & \multirow{2}{*}{0.284} \\
\hline \multirow{3}{*}{ Other } & 208 & & 235 & \\
\hline & \multicolumn{3}{|c|}{ Age } & \\
\hline & 21-30 & $31-40$ & $41-50$ & \\
\hline Third molar & 59 & 40 & 37 & \multirow{2}{*}{0.869} \\
\hline Other & 199 & 120 & 124 & \\
\hline
\end{tabular}


The angulation types of third molars causing root canal treatment of second molar teeth are shown in Figure 2.

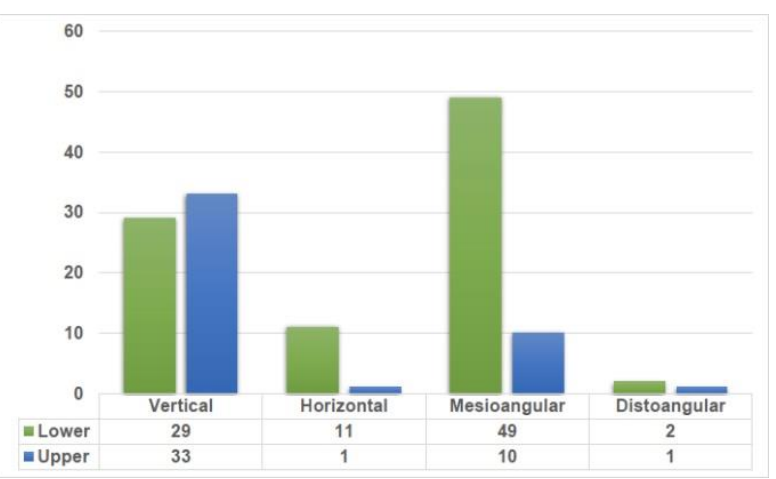

Figure 2. Angulation types of third molars causing root canal treatment of second molars.

No statistically significant differences were observed between third molar angulation and gender $(p=0.585)$ or age $(p=0.147)$. No statistically significant difference was found between partially and fully erupted third molars causing root canal treatment of second molars ( $p=$ 0.344 ). The eruption status of the third molars is shown in Figure 3. In patients undergoing second molar root canal treatment for reasons unrelated to third molars, $68 \%$ of the third molars were fully erupted (Figure 3).

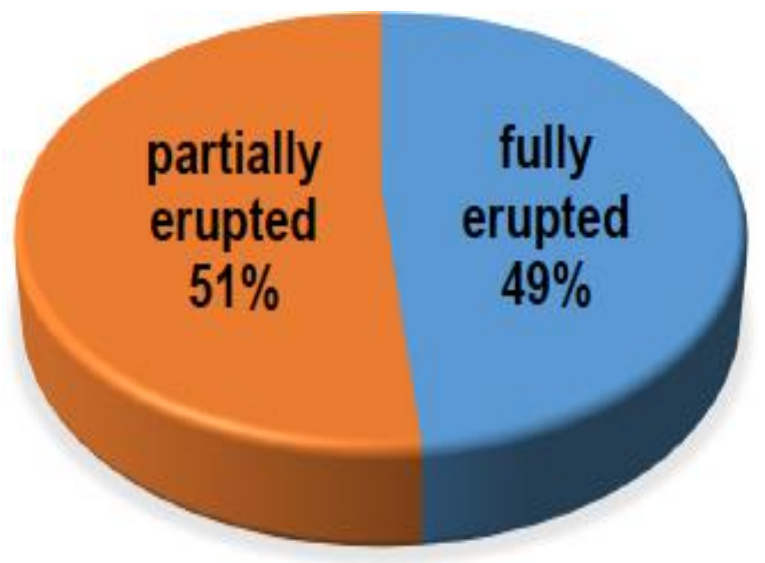

Figure 3. Eruption status of third molars causing root canal treatment of second molars.

Of the 579 second molars, 136 (23.5\%) underwent root canal treatment because of third molars. The rate of second molars undergoing root canal treatment for reasons not related to third molars was statistically higher than that of second molars undergoing treatment because of third molars $(p<0.001)$. The rate of lower second molars with endodontic treatment was significantly higher than that of upper second molars $(p<0.001)$. The locations and reasons for endodontic treatment of second molars are shown in Table 2.

Table 2. Reasons for Endodontic Treatment and Locations of Second Molars $(n=579)$

\begin{tabular}{llcr}
\hline & & $\boldsymbol{n}(\boldsymbol{\%})$ & $\boldsymbol{P}$ \\
\hline \multirow{2}{*}{ Reason } & Third molar & $136(23.5 \%)$ & $<0.001$ \\
& Other & $443(76.5 \%)$ & $<0.001$ \\
Location & Lower & $336(58 \%)$ & $243(42 \%)$ \\
& Upper & $24 \%$ & \\
\hline
\end{tabular}

\section{DISCUSSION}

Of the 579 second molars included in this study, $136(23.5 \%)$ underwent root canal treatment because of third molars and $443(76.5 \%)$ for other reasons, such as prosthetic or iatrogenic causes, failed vital pulp treatments, or caries other than distal caries. Dental caries are the most common second molar lesions seen on panoramic radiographs and most commonly affect second molars adjacent to impacted third molars at the cervical line. ${ }^{18}$ However, considerably more cases of external cervical resorption have been diagnosed with cone beam computed tomography than with panoramic radiography. ${ }^{21}$ In this study, external root resorption in second molars could not be assessed, as they were examined only on panoramic radiography and not on cone beam computed tomography. Therefore, all lesions were accepted as distal caries.

Third molars can cause second molars a number of problems. ${ }^{22}$ They may also cause pericoronitis, periodontal diseases, cyst or tumor formations, and systemic infections besides distal caries. ${ }^{4}$ These problems can be related to the inability to effectively clean the distal area. ${ }^{23}$ In cases of bacterial invasion of the pulp or of deep 
caries with spontaneous pain, endodontic treatment is inevitable. Other reasons for root canal treatment include trauma, failed root canal treatment, and restorative or prosthetic procedures. ${ }^{24}$

McArdle and Renton (2006) assumed that distal caries in a mandibular second molar is toothspecific and does not develop in the absence of a third molar. ${ }^{13}$ It has been reported that the incidence of distal caries in mandibular second molars is closely associated with mesial angulation and the distance between the distal cementoenamel junction of the mandibular second molar and the mesial cementoenamel junction of the mandibular third molar. ${ }^{12}$ The most common type is mandibular mesioangular angulation (48.3\%), followed by horizontal angulation $(29.3 \%){ }^{9}$ Knutsson et al. ${ }^{5}$ (1996) reported that mesioangular and horizontally positioned third molars are more likely to be associated with caries development in adjacent second molars. The incidence of distal caries in second molars associated with mesioangular third molars varies between countries. A rate of $12.6 \%$ has been reported in the Turkish population ${ }^{19}, 26 \%$ in the American population $^{5}, 38.53 \%$ in the Pakistani population ${ }^{25}$, $21.5 \%$ in the Jordanian population ${ }^{18}$, and $27.4 \%$ in the South Korean population. ${ }^{26}$ According to the results of these studies ${ }^{5,18,19,25,26}$, mesioangular third molars showed a high incidence of distal caries of the adjacent second molar. In this study, 49 of 91 (53.8\%) mandibular third molars that causing second molars to be treated endodontically were in mesioangular position. The reason for the higher rate in our study may be the fact that we did not examine the incidence of distal caries but second molars that required endodontic treatment because of mesioangular third molars. It was assumed that distal caries may have been noticed and treated restoratively before reaching the pulp. Therefore, this result may be difficult to compare with other studies.

Previous studies have reported that vertical angulation of third molars is the most common angulation in the maxilla., ${ }^{9,27,28}$ In this study, we did not investigate the frequency of each angulation type according to location. However, among the upper third molars, 10 teeth with a mesioangular angle and 33 with a vertical angle were found to cause root canal treatment of second molars. Third molars in the vertical position may indirectly cause caries on the distal side of second molars. Because flossing between the second and third molars can be difficult, interproximal caries may occur regardless of the third molar's angulation. Alhobail et $a l^{27}$ (2019) found no significant association between the distoangular position and the incidence of distal surface caries in second molars. Similarly, in this study, third molars in the distoangular position were not a high-risk factor for root canal treatment of second molars due to distal caries.

Altan et $a .^{29}$ (2018) have reported a significantly higher incidence of distal caries in the presence of a third molar in males than in females. In contrast, AlHobail et al. ${ }^{27}$ (2019) found that gender did not significantly affect the risk of distal surface caries in second molars because of third molars. Likewise, in this study, we observed no statistically significant difference between male and female patients in this respect.

In some studies, most patients were aged between 25 and $34 .{ }^{27,30}$ It has been suggested that the longer a third molar is exposed in the mouth, the higher the chance of caries developing on the distal surface of a second molar. ${ }^{12,31}$ Odirinu et al. ${ }^{22}$ (2012) found a strong association between an older age and the development of distal cervical caries in a second molar adjacent to an impacted mandibular third molar. In contrast, according to Altıparmak et $a l .{ }^{32}$, (2017) age does not correlate with the prevalence of distal caries lesions in second molars. The reason that we determined the age range for included patients as 21-50 years was that we frequently perform root canal treatments not only on young patients but also on middle-aged patients. In line with Altıparmak et al. ${ }^{32}$ (2017), we found no statistically significant relationship between age and second molars with endodontic treatment because of third molars $(p=0.869)$. This may be related to the fact that we only examined second molar teeth undergoing root canal treatment. Moreover, our results only reflect the rates of second molars undergoing endodontic treatment because of third molars. This study was a single- 
center study conducted in Istanbul. The rates could be different in other regions of Turkey, or between urban and rural areas.

The length of time required for a mesioangular or horizontal third molar to either fully or partially erupt is a critical factor in the development of distal caries in an adjacent second molar. ${ }^{33}$ Allen et al. ${ }^{15}$ (2009) found that distal second molar caries were present in $11 \%, 55 \%$, and $53 \%$ of unerupted, partially erupted, and fully erupted adjacent mesioangular third molars, respectively. Alhobail et al. ${ }^{27}$ (2019) reported a higher incidence of caries in second molars in the presence of fully erupted than impacted third molars. In our study, $51 \%$ of third molars associated with second molars undergoing root canal treatment were partially erupted, and $49 \%$ were fully erupted. In the case of second molars undergoing root canal treatment for other reasons, $68 \%$ of adjacent third molars were fully erupted. Although we found no statistically significant difference, these results suggest that partially erupted third molars lead to more caries and destruction of adjacent second molars. A partially erupted third molar could also lead to the need for extraction of a second molar. Therefore, we postulate that the damage caused by partially erupted third molars could be even greater.

In this study, we found a significantly higher rate of lower than upper second molars undergoing endodontic treatment $(p<0.001)$. Of the 136 second molars undergoing root canal treatment because of third molars, $45(33.1 \%)$ were in the maxilla and 91 (66.9\%) were in the mandible.

This study had some limitations. First, we only investigated second molars undergoing endodontic treatment because of lower and upper third molars and did not consider second molars undergoing restorative treatment because of third molars. If the latter had been included in the study, the rates may have been different. Second, we only included patients with second molars undergoing root canal treatment that had adjacent third molars. Inclusion of patients undergoing second molar root canal treatment following third molar extraction may have altered the results. Finally, the fact that this was a single-center study and the fact that certain potentially influencing factors (such as oral hygiene and lifestyle habits) were not considered could also accepted as limitations.

The strength of this study was that it was the first study to investigate upper third molars causing distal caries in second molars or second molars treated endodontically because of upper and lower third molars. Therefore, we believe that our findings make a significant contribution to the literature.

\section{CONCLUSIONS}

This retrospective study found an association between second molars undergoing root canal treatment and fully or partially erupted third molars. Control of third molars with regular radiographs is recommended. Further studies are needed to establish whether prophylactic removal of a third molar should be considered. Optimal oral hygiene practices are recommended for patients who do not wish to have their third molars extracted.

\section{ACKNOWLEDGEMENTS}

None.

The authors deny any conflicts of interest related to this study.

$\ddot{O} Z$

Amaç: Bu çalışmada klsmen veya tamamen sürmüş alt ve üst üçüncü molar dişlere bağll olarak endodontik tedavi gören ikinci molar dişlerin oranlart değerlendirilmiştir. Gereç ve Yöntemler: Ü̧̧üncü molar dişler ve diğer nedenlerle endodontik tedavi yapılan ikinci molarları saptamak için 579 hastadan alınan radyografik veriler analiz edilmişstir. Tanımlayıcı istatistikler, kategorik değişkenler için sayı ve yüzde olarak ifade edilmişstir. Istatistiksel analiz için Ki-Kare testi kullanllmıştır $(p<0,05)$. Bulgular: Ü̧̧üncü molar dişlerden bağımsız olarak kök kanal tedavisi gören ikinci molar dişlerin oranı, üçüncü molar dişler nedeniyle tedavi gören ikinci molarlarin oranindan istatistiksel olarak daha yüksek bulunmuştur. $(p<0,001)$ Endodontik tedavi gören alt ikinci molar dişlerin oranının, üst ikinci molar dişlere oranla daha fazla olduğu tespit edilmiştir $(p<0,001)$. İkinci molar dişlerin kök kanal tedavisi görmesine neden olan klsmen veya tamamen sürmüş üçüncü molar dişler arasinda istatistiksel olarak anlaml bir farklllik bulunamamıştır ( $p=0,344)$. Sonuç: İkinci molar dişlerin kök kanal 
tedavisi tamamen veya kısmen sürmüş üçüncü molar dişler ile ilişkili olabilir. Kök kanal tedavisi ihtiyacını önlemek için tüm önleyici tedbirler alınmalıdır. Anahtar Kelimeler: Diş çürüğü, Endodonti, kök kanal tedavisi, üçüncü molar diş.

\section{REFERENCES}

1. Legovic M, Legovic I, Brumini G, et al. Correlation between the pattern of facial growth and the position of the mandibular third molar. J Oral Maxillofac Surg. 2008;66:1218-1224.

2. Breik O, Grubor D. The incidence of mandibular third molar impactions in different skeletal face types. Aust Dent J. 2008;53:320

3. Hassan H. Pattern of third molar impaction in a Saudi population. Dove Press J Clin Cosmet Investig Dent. 2010;2:109-113.

4. Bataineh AB, Albashaireh ZS, Hazza'a AM. The surgical removal of mandibular third molars: a study in decision making. Quintessence Int. 2002;33:613-617.

5. Knutsson K, Brehmer B, Lysell L, et al. Pathoses associated with mandibular third molars subjected to removal. Oral Surg Oral Med Oral Pathol Oral Radiol Endod. 1996;82:10-17.

6. Fejerskov O, Kidd E. Dental Caries: The Disease and Its Clinical Management. 2nd ed. Oxford: Blackwell Publishing Ltd.; 2008.

7. Alling CC, Helfrick JF, Alling RD. Impacted Teeth. Philadelphia: W.B. Saunders; 2003.

8. Winter GB. Impacted mandibular third molar. St. Louis: American Medical Book Co. 1926;241-279.

9. Hashemipour, MA, Tahmasbi-Arashlow, M, Fahimi-Hanzaei, F. Incidence of impacted mandibular and maxillary third molars: a radiographic study in a Southeast Iran population. Med Oral Patol Oral Cir Bucal. 2013;18(1):140-145.

10. Pillai AK, Thomas S, Paul G, et al. Incidence of impacted third molars: a radiographic study in People's hospital, Bhopal India. J Oral Biol Craniofac Res 2014;4:76-81.

11. Falci SGM, de Castro CR, Santos RC, et al. Association between the presence of a partially erupted mandibular third molar and the existence of caries in the distal of the second molars. Int J Oral Maxillofac Surg. 2012;41:1270.

12. Chang SW, Shin SY, Kum KY, et al. Correlation study between distal caries in the mandibular second molar and the eruption status of the mandibular third molar in the Korean population. Oral Surg Oral Med Oral Pathol Oral Radiol Endod. 2009;108:838-843.

13. McArdle L, Renton T. Distal cervical caries in the mandibular second molar: an indication for the prophylactic removal of the third molar? $\mathrm{Br} \mathrm{J}$ Oral Maxillofac Surg. 2006;44:42-45.

14. Magnusson BO, Sundell SO. Stepwise excavation of deep carious lesions in primary molars. J Int Assoc Dent Child. 1977;8:36-40.

15. Allen RT, Witherow H, Collyer $J$, et al. The mesioangular third molar-to extract or not to extract? Analysis of 776 consecutive third molars. Br Dent J. 2009;206:223.

16. Caplan DJ, Kolker J, Rivera EM, et al. Relationship between number of proximal contacts and survival of root canal treated teeth. Int Endod J. 2002;35:193-199. 17. Dhanrajani P, Smith M. Lower third molars. Natl J Maxillofac Surg. 2014;5:245-246.

18. Al-Khateeb TH, Bataineh AB. Pathology associated with impacted mandibular third molars in a group of Jordanians. J Oral Maxillofac Surg 2006;64:1598-1602. 19. Polat HB, Ozan F, Kara I, et al. Prevalence of commonly found pathoses associated with mandibular impacted third molars based on panoramic radiographs in Turkish population. Oral Surg Oral Med Oral Pathol Oral Radiol Endod. 2008;105:41-47.

20.20.Knutsson K, Brehmer B, Lysell L, et al. Asymptomatic mandibular third molars: oral surgeons' judgment of the need for extraction. J Oral Maxillofac Surg. 1992;50:329-333.

21. Oenning ACC, Melo SLS, Groppo FC, et al. Mesial inclination of impacted molars and its propensity to stimulate external cervical resorption in second molars; a cone beam computed tomographic evaluation. J Oral Maxillofac Surg. 2015;73:379-386.

22. Oderinu OH, Adeyemo WL, Adeyemi MO, et al. Distal cervical caries in second molars associated with impacted mandibular third molars: a case-control study. Oral Surg Oral Med Oral Pathol Oral Radiol 2012;12: 91-95.

23. Lysell L, Rohlin M. A study of indications used for removal of the mandibular third molar. Int $\mathrm{J}$ Oral Maxillofac Surg. 1988;17:161-164. 
24. Saad AY, Clem WH. An evaluation of etiologic factors in 382 patients treated in a post graduate endodontics program. Oral Surg. 1988; 65: 91-93.

25. Ali S, Nazir A, Shah SAA, et al. Dental caries and pericoronitis associated with impacted mandibular third molars - a clinical and radiographic study. Pak Oral Dent J. 2014;34:268-273

26. Jung YH, Cho BH. Prevalence of missing and impacted third molars in adults aged 25 years and above. Imaging Sci Dent. 2013;43:219-225.

27. AlHobail SQ, Baseer MA, Ingle NA, et al. Evaluation Distal Caries of the Second Molars in the Presence of Third Molars among Saudi Patients. J Int Soc Prev Community Dent. 2019;30:505-512.

28. Quek SL, Tay CK, Tay KH, et al. Pattern of third molar impaction in a Singapore Chinese population: a retrospective radiographic survey. Int J Oral Maxillafac Surg. 2003;32:548-552.
29. Altan A, Soylu E. The Relationship Between the Slope of the Mesioangular Lower Third Molars and the Presence of Second Molar Distal Caries: A Retrospective Study. Cumhuriyet Dent J. 2018;21:178-183.

30. Kumar VR, Yadav P, Kahsu E, et al. Prevalence and pattern of mandibular third molar impaction in Eritrean population: A retrospective study. J Contemp Dent Pract. 2017;18:100-106.

31. Ozeç I, Hergüner Siso S, Tasdemir U, et a. Prevalence and factors affecting the formation of second molar distal caries in a Turkish population. Int J Oral Maxillofac Surg. 2009;38:1279- 1282.

32. Altiparmak N, Oguz Y, Neto RS, et al. Prevalence of distal caries in mandibular second molars adjacent to impacted third molars: a retrospective study using panoramic radiography. J Dent Health Oral Disord Ther. 2017;8(6):641-645.

33. Toedtling V, Coulthard P, Thackray G. Distal caries of the second molar in the presence of a mandibular third molar-a prevention protocol. Br Dent J. 2016;221:297302. 